\title{
PELATIHAN KEWIRAUSAHAAN DALAM MEWUJUDKAN KEMANDIRIAN EKONOMI BAGI SISWA SEKOLAH MENENGAH KEJURUAN (SMK) PGRI DI SURAKARTA
}

\author{
Shandy Marsono ${ }^{1}$, Lilis Sulistyani ${ }^{2}$, Ifah Lathifah ${ }^{3}$ \\ STIE Adi Unggul Bhirawa Surakarta \\ Email: ${ }^{2}$ lilissulistyani44@yahoo.co.id; ${ }^{3 i \text { fahtifa@yahoo.co.id }}$
}

\begin{abstract}
ABSTRAK
Pengabdian ini bertujuan memberikan pelatihan kewirausahaan dalam rangka membangun kemandirian ekonomi bagi siswa Sekolah Menengah Kejuruan (SMK) Persatuan Guru Republik Indonesia (PGRI) di Surakarta.

Kegiatan pelatihan kewirausahaan dalam rangka membangun kemandirian ekonomi akan dilakukan dengan cara presentasi, diskusi dan simulasi. Sasaran dari kegiatan Pengabdian Kepada Masyarakat ini adalah siswa Sekolah Menengah Kejuruan (SMK) Persatuan Guru Republik Iindonesia (PGRI) di Surakarta. Solusi yang ditawarkan oleh tim pengabdian kepada masyarakat STIE-AUB-Surakarta untuk mengatasi permasalahan yang dihadapi oleh siswa Sekolah Menengah Kejuruan (SMK) Persatuan Guru Republik Indonesia (PGRI) di Surakarta yaitu Tim PKM STIE-AUB-Surakarta akan mengadakan pelatihan kewirausahaan bagi siswa Sekolah Menengah Kejuruan (SMK) khususnya bagi siswa Sekolah Menengah Kejuruan (SMK) PGRI di Surakarta.

Hasil dari kegiatan setelah dilakukan pelatihan, binaan dan pendampingan, para peserta yaitu siswa Sekolah Menengah Kejuruan (SMK) Persatuan Guru Republik Indonesia (PGRI) Surakarta sangat antusias untuk dapat menjalankan praktik berwirausaha. Siswa Sekolah Menengah Kejuruan (SMK) semakin termotivasi untuk menghasilkan produk disamping karena tuntutan dari sekolah, tetapi juga untuk menghasilkan produk- produk kreatif sebagai langkah awal mampu mandiri secara ekonomi. Harapan lebih jauh ke depan dari siswa Sekolah Menengah Kejuruan (SMK), mereka benar-benar dapat memiliki jiwa berwirausaha sebagai bekal untuk terjun dalam masyarakat.

Saran yang dapat disampaikan oleh Tim PKM STIE-AUB- Surakarta, bahwa pihak Sekolah Menengah Kejuruan (SMK) PGRI Surakarta perlu membuat klinik wirausaha atau entrepreneur bagi siswa. Para siswa Sekolah Menengah Kejuruan (SMK) setelah lulus diharapkan mampu menciptakan lapangan kerja bagi diri sendiri dan bahkan bagi masyarakat luas.
\end{abstract}

Kata Kunci: Kewirausahaan, siswa, Sekolah Menengah Kejuruan, kemandirian ekonomi.

\section{Pendahuluan}

Kewirausahaan memainkan peran yang penting dalam pertumbuhan ekonomi dan standar kehidupan Negara tidak terkecuali negara Indonesia. Dalam pertumbuhan ekonomi negara bahwa kegiatan pembangunan tidak hanya memerlukan pembentukan modal (dari dalam dan luar negri), namun juga memerlukan pembentukan wirausaha-wirausaha. Para wirausahawan ini menjadi pencipta kesempatan kerja baru, inovasi baru, penghasilan baru, pembayaran pajak baru yang akan menjadi sumber pertumbuhan ekonomi terutama bagi negara-negara sedang berkembang. Negara dengan demikian tidak hanya bergantung pada pinjaman dalam negeri berupa pinjaman kepada rakyat melalui penarikan pajak maupun pinjaman - pinjaman dari luar negeri.

Wirausaha dapat diartikan sebagai konsep kemampuan untuk menciptakan sesuatu yang baru dan berbeda untuk menghasilkan nilai tambah namun dengan mempunyai keberaniaan untuk menghadapi resiko atau ketidak pastian. Hal-hal yang mendorong perhatian terhadap kewirausahaan yaitu pada berbagai negara yang sudah maju ternyata banyak bermunculan inovasi-inovasi baru dan kesempatan kerja berkaitan dengan pendirian usaha kecil dan menengah yang biasa disebut enterepeneurial venture.

Di Indonesia, gerakan berwirausaha telah dicanangkan oleh pemerintah secara serius dengan sasaran bidik para siswa Sekolah Menengah Kejuruan (SMK). Menurut Gatot Hari Priowirjanto selaku Direktur The Southeast Asian Ministers of Education Organization (SEAMEO) bahwa SMK menjadi pencetak wirausaha merupakan bagian dari upaya pemerintah mencapai target Revitalisasi SMK sesuai Instruksi Presiden Nomor 9 Tahun 2016. Kewirausahaan di kalangan siswa sekolah menengah kejuruan (SMK) terus dikembangkan. Direktorat Pembinaan sekolah menengah kejuruan (SMK). 
Kementerian pendidikan dan kebudayaan, lewat program bantuan pengembangan pembelajaran kewirausahaan SMK memberikan dorongan kepada para kepala sekolah untuk melahirkan lebih banyak wirausaha muda dari SMK. Kepala Subdirektorat Kurikulum Direktorat Pembinaan SMK Mochamad Widiyanto dalam keterangan tertulis, dikutip dari laman resmi Kemdikbud (6/6/2018) menyatakan bahwa "Program sekolah pencetak wirausaha ini untuk mengintegrasikan konsep BMW yaitu Bekerja, Melanjutkan Studi, Wirausaha".

Di wilayah Surakarta, khususnya pada Sekolah Menengah Kejuruan (SMK) Persatuan Guru Republik Indonesia (PGRI) Surakarta tidak dapat lepas dari kewajiban untuk mencetak wirausahawirausaha baru sebagai profil lulusan. Kendala yang muncul di lapangan adalah bahwa pihak sekolah sendiri memiliki keterbatasan untuk mencapai tujuan tersebut. Para siswa SMK dalam proses pembelajaran hanya harus memenuhi kewajiban untuk menghasilkan produk sesuai dengan tuntutan dari jurusan yang diambil. Pengembangan kurikulum di sekolah dan tenaga pendidik di bidang kewirausahaan, nampaknya juga menjadi kendala tersendiri bagi pihak sekolah.

Tim pengabdian kepada masyarakat (PKM) Sekolah Tinggi Ilmu Ekonomi - AUB - Surakarta, khususnya jurusan Akuntansi berdasarkan fenomena di lapangan merasa sangat terpanggil untuk memberikan sumbangan pemikiran bagi siswa - siswa Sekolah Menengah Kejuruan (SMK) PGRI di Surakarta. Kepedulian ini diwujudkan dalam langkah nyata berupa rencana dilakukannya pelatihan kewirausahaan dalam rangka membangun jiwa berwirausaha bagi para siswa Sekolah Menengah Kejuruan (SMK). Harapan lebih jauh ke depan dari kegiatan PKM ini, siswa Sekolah Menengah Kejuruan (SMK) benar-benar dapat memiliki jiwa berwirausaha sebagai bekal untuk terjun dalam masyarakat. Para lulusan Sekolah Menengah Kejuruan (SMK) mampu menciptakan lapangan kerja bagi diri sendiri dan bahkan bagi masyarakat luas. .

\section{Perumusan Masalah}

Pemerintah Indonesia melalui Kementrian Pendidikan Dasar dan Menengah mempunyai kebijakan untuk meningkatkan rasio SMK lebih besar daripada SMA, yaitu 67\% SMK dan 33\% SMA (Renstra Kemendiknas 2010-2014). Penyebab perubahan jumlah sekolah yaitu data yang ada di lapangan bahwa pengangguran produktif paling banyak adalah lulusan SMA, karena SMA diprogram untuk siswa yang setelah lulus nantinya akan melanjutkan ke jenjang pendidikan yang lebih tinggi,. Adapun lulusan siswa dari SMK diharapkan siswa setelah lulus siap bekerja atau menciptakan lapangan pekerjaan. Kendalanya adalah bahwa siswa SMK dalam proses pembelajaran, hanya memperoleh materi ajar mengenai bagaimana siswa menjadi terampil untuk menghasilkan produk luaran sesuai dengan jurusan yang diambil. Siswa tidak atau kurang mendapatkan bekal ilmu mengenai bagaimana siswa dapat lebih kreatif untuk menghasilkan produk-produk inovatif serta bagaimana keterampilan siswa tersebut dikembangkan menjadi kemampuan berwiraniaga. Berdasarkan kondisi lapangan atau fenomena tersebut menimbulkan keprihatinan dan permasalahan yaitu bagaimana membangun jiwa berwirausaha bagi para siswa Sekolah Menengah Kejuruan (SMK) PGRI di Surakarta untuk mempersiapkan diri setelah lulus dari sekolah ?"'

\section{Kerangka Pemecahan Masalah}

Kerangka pemecahan masalah yang ditawarkan oleh Tim pengabdian kepada masyarakat STIEAUB-Surakarta untuk mengatasi permasalahan yang dihadapi oleh pihak sekolahan ataupun siswa Sekolah Menengah Kejuruan (SMK), khususnya di SMK PGRI Surakarta, yaitu Tim PKM akan mengadakan pelatihan kewirausahaan dalam rangka membangun jiwa berwirausaha dan kemandirian ekonomi bagi siswa. Kegiatan ini akan diawali dengan penyampaian materi tentang kewirausahaan dan dilanjutkan dengan pelatihan bagaimana membangun wirausaha. Kegiatan ini diharapkan dapat 
meumbuhkan jiwa berwirausaha bagi para siswa dan setelah lulus sekolah akan diterapkan, sehingga para lulusan SMK dapat menciptakan lapangan kerja bagi diri sendiri atau pun bagi masyarakat.

\section{Metode Kegiatan}

Adapun metode kegiatan yang dilakukan meliputi :

a. Penyuluhan, yaitu memberikan materi kewirausahaan kepada siswa Sekolah Menengah Kejuruan (SMK) agar siswa dapat mengenal dan memahami secara baik tentang kewirausahaaan dan bagaimana membangun jiwa berwirausaha.

b. Pelatihan, yaitu memberikan pelatihan bagaimana memulai berwirausahaan kepada siswa Sekolah Menengah Kejuruan (SMK), agar siswa SMK setelah lulus dapat mandiri secara ekonomi dengan menjual produk yang dihasilkan siswa sendiri. Para siswa Sekolah Menengah Kejuruan (SMK) juga akan dibina agar dapat mengenali diri sendiri, sehingga dapat mengembangkan jiwa berwirausaha yang ada dalam diri siswa.

\section{Hasil, Pembahasan Dan Dampak}

Kegiatan Pengabdian Kepada Masyarakat (PKM) STIE - AUB - Surakarta yang diselenggarakan dengan khlayak sasaran siswa Sekolah Menengah Kejuruan (SMK) PGRI Surakarta telah berjalan dengan baik dan lancar. Para siswa dan juga guru di SMK PGRI Surakarta sangat antusias mengikuti kegiatan PKM ini. Beberapa siswa secara terbuka menyampaikan keinganan mereka untuk secara lebih intensif menerima bimbingan atau pendampingan, agar benar-benar mampu merintis usaha sendiri atau berwirausaha.

Kewirausahaan memainkan peran yang berpengaruh dalam pertumbuhan ekonomi dan standar kehidupan negara. Pertanyaan yang muncul adalah mengapa demikian?. Jawaban yang logis yaitu bahwa wirausaha berperan sebagai:

a. Pencipta Kekayaan dan Berbagi

b. Penghasil atau pencipta lapangan Pekerjaan

c. Pembangun ekonomi Regional yang Seimbang

d. Penopang peningkatan standar kehidupan masyarakat

e. Pelaku ekspor untuk memperluas bisnis ke pasar luar negeri

f. Penopang peningkatan PDB dan Per Kapita

g. Pencipta bisnis baru sebagai tanggapan terhadap kebutuhan dan permintaan yang tidak terpenuhi di pasar seperti produk layanan.

Direktorat Pembinaan sekolah menengah kejuruan (SMK). Kementerian pendidikan dan kebudayaan, lewat program bantuan pengembangan pembelajaran kewirausahaan Sekolah Menengah Kejuruan menaruh harapan besar bahwa para lulusan SMK akan mampu menjadi wirausah-wirausaha baru di Indonesia pada masa yang akan datang. Hal ini selaras dengan pernyataan dari Direktorat Pembinaan SMK Mochamad Widiyanto dikutip dari laman resmi Kemdikbud (6/6/2018) menyatakan bahwa SMK adalah "Program sekolah pencetak wirausaha ini untuk mengintegrasikan konsep BMW yaitu Bekerja, Melanjutkan Studi, Wirausaha".

Di Sekolah Menengah Kejuruan (SMK) Persatuan Guru Republik Indonesia (PGRI) Surakarta memang telah ada kurikulum mata pelajaran tentang kewirausahaan. Pelajaran kewirausahaan yang ada di SMK tidak cukup hanya diberikan secara teori saja, namun harus disertai dengan praktik praktik nyata seperti penyediaan toko untuk menjual/memasarkan produk hasil karya siswa. Para siswa juga sekaligus yang menjaga Toko atau yang menawarkan produk ke perusahaan pengguna potensial dari produk yang dihasilkan siswa. 
Pihak Sekolah Menengah Kejuruan (SMK) Persatuan Guru Republik Indonesia (PGRI) Surakarta, selayaknya juga memiliki web site yang dapat digunakan sebagai e-shopping untuk produk hasil kreasi siswa. Atau pihak SMK PGRI juga perlu menjalin network dengan pihak sponsor atau perusahaan pengguna potensial, sehingga pengenalan dan pemasaran produk hasil karya siswa akan memiliki jaringan yang lebih luas. Tim Pengabdian Kepada Masyarakat dari perguruan tinggi atau bahkan para entrepreneur muda yang telah berhasil di bidang usahanya, kiranya juga perlu dihadirkan di SMK PGRI untuk memberikan pencerahan atau motivasi bagi para siswa. Para siswa SMK PGRI dengan demikian akan semakin termotivasi untuk berlatih menjadi wirausahawan karena mendapat dukungan penuh dari pihak sekolah.

\section{Kesimpulan Dan Saran}

Pelaksanaan kegiatan Pengabdian Kepada Masyarakat (PKM) STIE - AUB - Surakarta yang telah diselenggarakan dengan khlayak sasaran siswa Sekolah Menengah Kejuruan (SMK) PGRI Surakarta, menghasilkan kesimpulan :

a. Para siswa Sekolah Menengah Kejuruan (SMK) PGRI Surakarta, sebagai peserta kegiatan pelatihan sangat antusias atau termotivasi untuk berwirausaha.

b. Guru pendamping siswa kegiatan pelatihan juga sangat antusias dengan kegiatan ini dan berharap secara bertahap kemauan siswa untuk menghasilkan produk-produk kreasi atau inovatif semakin baik atau tinggi.

c. Kegiatan pelatihan ini telah membuka wawasan para siswa SMK dalam proses pengembangan jiwa berwiausaha, untuk menuju kemandirian ekonomi setelah siswa lulus dari pendidikan advokasi.

d. Tindak lanjut dari kegiatan ini perlu dilakukan baik berupa binaan dan pendampingan berkelanjutan, sehingga peserta pendampingan khususnya siswa SMK PGRI di Surakarta dapat menjalankan praktik berwirausaha. Harapan lebih jauh ke depan, dari kegiatan tindaklanjut ini adalah siswa lulusan dari SMK ini akan mampu berwirausaha untuk menghasilkan produk-produk inovatif, sehingga dapat menciptakan lapangan kerja bagi diri sendiri bahkan bagi masyarakat sekitarnya.

Hal-hal yang perlu digarisbawahi berdasarkan hasil kesimpulan di atas adalah berupa saran untuk pengembangan koperasi pada waktu mendatang, sehingga kegiatan ini akan memotivasi warga masyarakat sebagai pengurus dan pegawai koperasi untuk dapat memenuhi kewajiban sesuai dengan ketentuan yang telah disepakati bersama di koperasi. Kegiatan di masa yang akan datang, agar dilakukan pendampingan yang lebih terstruktur, materi juga harus disesuaikan dengan kebutuhan para pengurus dan anggota koperasi. Berdasarkan saresehan yang dilakukan antara Tim PKM STIE-AUBSurakarta dengan pengurus koperasi, pendampingan berikutnya yang dibutuhkan oleh pengurus koperasi adalah bidang kewirausahaan berupa pemasaran produk abon lele dan karak tanpa borak. Dua Jenis produk ini sangat menjanjikan sebagai penopang ekonomi masyarakat, namun kendala yang dihadapi adalah pemasaran hasil produksi.

Beberapa saran yang dapat disampaikan oleh Tim Pengabdian Kepada Masyarakat (PKM) setelah pelaksanaan kegiatan ini antara lain:

1. Pihak Sekolah Menengah Kejuruan (SMK) PGRI Surakarta, perlu untuk terus meningkatkan jiwa berwirausaha bagi para siswa dengan membentuk klinik-klinik wirausaha, membuat outlet atau membuat e-shopping untuk menjual/memasarkan produk-produk hasil kreasi para siswa.

2. Pihak Sekolah Menengah Kejuruan (SMK) PGRI Surakarta, secara periodik/berkala mendatangkan entrepreneur - entrepreneur muda sebagai pembicara untuk lebih memotivasi para siswa untuk mengembangkan jiwa berwirausaha.

3. Pihak Sekolah Menengah Kejuruan (SMK) PGRI Surakarta dapat merintis jaringan (network) ke perusahaan - perusahaan calon pengguna produk hasil kreasi siswa. 


\section{UCAPAN TERIMAKASIH}

Dalam kesempatan ini pula, kami Tim Pengabdian Kepada Masyarakat STIE - AUB Surakarta mengucapkan terimakasih, yang pertama kepada pimpinan Sekolah Tinggi Ilmu Ekonomi Adi Unggul Bhirawa Surakarta khususnya Lembaga Penelitian dan Pengabdian Pada Masyarakat yang telah memberikan ijin dan menyediakan sarana dan prasarana kegiatan ini. Kedua, bagi para siswa dan guru di Sekolah Menengah Kejuruan (SMK) Persatuan Guru Republik Indonesia (PGRI) Surakarta atas partisipasi dan kerjasama yang telah diberikan, sehingga kegiatan pengabdian masyarakat dapat terlaksana dengan baik dan lancar sesuai dengan yang direncanakan.

Kami menyadari bahwa kegiatan pengabdian kepada masyarakat ini tidak luput dari kekurangan, sehingga segala kritik dan saran yang membangun senantiasa kami harapkan dan akan kami terima dengan senang hati. Akhir kata kami sangat berharap, semoga hasil dari kegiatan pengabdian kepada masyarakat ini dapat bermanfaat dan akan disusul dengan kegiatan berikutnya yang berkesinambungan.

\section{REFERENSI}

Achmad, Nur. 2015. Kewirausahaan: Suatu Alternatif Lain Menuju Kesuksesan. Surakarta: BPK FEB UMS.

Alma, B. 2011. Kewirausahaan (Edisi Revisi). Bandung: Alfabeta

Effendy, Mochtar.2010.Kewirausahaan (Entrepreneurship) Tuntunan Untuk Praktisi. Yayasan Penerbit Al-Mukhtar : Palembang.

Kasmir. 2010. Kewirausahaan. Jakarta: PT Raja Grafindo Persada

Maslow,Abraham H.1984.Motivasi dan Kepribadian.Jakarta : PT Gramedia. Peace II, 2009. Management. New York: McGraw-Hill Book.

Prasetyo,Bambang dan Lina Miftahul Jannah. 2005. Metode Penelitian Kuantitatif; Teori Dan Aplikasi. Jakarta : PT Rajagrafindo Persada.

Saputro, Edy Purwo., Achmad, Nur dan Handayani, Sih. 2016. Identifikasi Faktor yang Mempengaruhi Sukses Wirausaha. Benefit, Jurnal Manajemen dan Bisnis. Volume 1, Nomor 1.

Sardiman. 2011. Interaksi dan Motivasi Belajar Mengajar. Jakarta: Rajawali Pers.

Siswanto. 2003. Salesmanship: Keahlian Menjual Barang Dan Jasa.Edisi Kedua.Damar Mulia Pustaka,Jakarta.

Sudrajat, Akhmad. 2011. Konsep Kewirausahaan dan Pendidikan Kewirausahaan di Sekolah. Diakses tanggal 16 Oktober 2016 dari http://akhmadsudrajat.wordpress.com/2011/06/29/konsep kewirausahaan dan pendidikan-kewirausahaan/.

Subandono, Aris. 2007. Pengaruh Life Skill Diklat Kimia Produktif dan Prestasi Belajar Diklat Kewirausahaan terhadap Minat Berwirausaha pada Siswa SMK Kimia Industri Theresiana Semarang. Skripsi. FMIPA-UNES. 
Suryana, 2006. Kewirausahaan Pedoman Praktis: Kiat dan Proses Menuju.Sukses, Edisi Ketiga, Penerbit Salemba, Jakarta.

Widhari, Cokorda Istri Sri, I Ketut Suarta.2012. Kewirausahaan Pedoman Praktis: Kiat dan Proses menuju Sukses. Jakarta: Salemba Empat.

Yuyun Wirasasmita. 2003. Komunikasi Bisnis. Jakarta : PT Gramedia Pustaka Utama.

Zimmerer, Thomas W dan Scarborough, Norman M. 2008. Kewirausahaan dan Manajemen.UsahaKecil, Jakarta: Salemba Empat 